\title{
Oligopsonistic Cats and Dogs
}

\author{
Gerda Dewit \\ National University of Ireland Maynooth
}

\author{
Dermot Leahy \\ University College Dublin
}

June 2005

Abstract: We study the strategic investment behaviour of oligopsonistic rivals in the labour market. Under wage competition, firms play "puppy dog" with productivityaugmenting investment and "fat cat" with supply-enhancing investment. Under employment competition, investing strategically always involves playing "top dog".

JEL Codes: L13, J42.

Key words: Oligopsony, Strategic behaviour, Productivity-augmenting investment, Supply-enhancing investment.

Acknowledgements: This research is supported by the International Trade and Investment programme of the Geary Institute at UCD.

Correspondence: Gerda Dewit, National University of Ireland, Maynooth, Department of Economics, Maynooth, Ireland, tel.: (+)353-(0)1-7083776, fax: (+)353-(0)1-7083934, Email: Gerda.Dewit@nuim.ie; Dermot Leahy, University College Dublin, Department of Economics, Belfield, Dublin 4, Ireland, tel.: (+)353-(0)1-7168551, fax: (+)353-(0)12830068,E-mail: Dermot.M.Leahy@ucd.ie. 


\section{Introduction}

Since it was first conceived, the Fudenberg-Tirole "Cats and Dogs" taxonomy of business strategies (Fudenberg and Tirole, 1984) has become the standard framework for characterising investment behaviour in an oligopolistic set-up. Ensuing work has produced interesting applications (Neary and Leahy (2000)) and refinements of the initial taxonomy (Lapham and Ware (1994), Jun and Vives (2004)). Common to all of these is the concern with investment strategies that reinforce a firm's position in the output market. Remarkably, the strategic investment behaviour of firms that want to strengthen their position in the input market has not been formally analysed. This paper aims to fill that gap in the literature.

While our analysis applies to input markets in general, we focus on the labour market in particular. This choice is a natural one, especially when viewed in light of recent developments in labour economics. Convincing arguments have been presented to defend the belief that the labour market -like many other markets- is essentially imperfectly competitive, thereby challenging the old paradigm of perfect competition in the labour market (Manning, 2003). Proponents of this school of thought argue that the labour supply curve facing an individual firm is typically not infinitely elastic but upward sloping, therefore making firms' behaviour monopsonistic or oligopsonistic ${ }^{1}$.

In this paper, we present a taxonomy of investment strategies for firms that have oligopsony power in the labour market and highlight possible implications of labour market policies on strategic investment.

\section{The model}

Two firms, $i$ and $j$, play a two-period game. In the second period, firms act as duopsonists in the labour market. They decide simultaneously, either setting wages (we call this "wage competition") or employment levels ("employment competition"). For

\footnotetext{
${ }^{1}$ More specifically, Manning (2003) argues that all that is required for a firm's labour supply curve to be upward sloping is that a wage cut of one cent does not cause all workers to leave the firm immediately. He presents empirical evidence that supports this and explains it by referring to the existence of "local" labour
} 
conciseness, we solve the model in terms of general "actions" $\left(A^{h}, h=i, j\right)$ and then discuss the implications for wage $\left(A^{h}=w^{h}\right)$ and employment competition $\left(A^{h}=L^{h}\right)$, respectively. Firm $i$ faces the labour supply function:

$L^{i}=L^{i}\left(w^{i}, w^{j}\right)$

Henceforth, partial derivatives with respect to actions are subscripted, with $A, L$ and $w$ being suppressed in subscripts where this cannot cause confusion (for instance, $\left.L_{j}^{i} \equiv \partial L^{i} / \partial w^{j}\right)$. A rise in firm $i$ 's wage attracts more labour $\left(L_{i}^{i}>0\right)$; a fall in its rival's wage pushes workers towards firm $i\left(L_{j}^{i}<0\right)$. For simplicity, we assume perfect competition in the goods market, implying that a firm's product price, $p^{h}$, is given.

In period one, firm $i$ chooses an investment level, $K$. For clarity and simplicity, we assume only one firm invests (as do Fudenberg and Tirole (1984)) ${ }^{2}$. First, we consider the case in which $K$ has a positive effect on the investing firm's marginal labour productivity. We call this form of investment "productivity-augmenting" (PA). Alternatively, investment may cause an outward shift in the labour supply curve facing a firm (examples include job advertising as well as within-firm crèche facilities, a commuter shuttle service for firm employees, recreational areas surrounding offices $-\mathrm{a}$ nice dining hall, a spacious coffee room, a green zone). This alternative form of investment will be labelled as "supply-enhancing” (SE). In both cases, firms' profits $(\pi)$ are given by expressions (2) and (3):

$\pi^{i}=p^{i} q^{i}-w^{i} L^{i}-C^{i}(K)$

$\pi^{j}=p^{j} q^{j}-w^{j} L^{j}$

Firm output is denoted by $q^{h}$. $C^{i}$ represents firm $i$ 's cost of investment, with marginal $\operatorname{cost} C_{K}^{i}>0$ and second derivative $C_{K K}^{i} \geq 0$.

markets (which occur, for instance, because of a desire to avoid congestion and/or cut commuting time to meet the demands of family life).

${ }^{2}$ Extending the model to allow investment by both firms is straightforward. 
With PA investment, firm i's output function is given by $q^{i}=q^{i}\left(L^{i}, K\right)$ with partial derivatives $q_{L^{i}}^{i}>0, q_{L^{i} L^{i}}^{i} \leq 0$ and $q_{K}^{i}>0$. Because investment raises labour productivity, $q_{i K}^{i}>0$. Since we assume that firm $j$ does not invest, its output function simply is $q^{j}=q^{j}\left(L^{j}\right)$ with $q_{L^{j}}^{j}>0$ and $q_{L^{j} L^{j}}^{j} \leq 0$. If firms set wages, we use the direct labour supply function in expression (1). With employment-setting firms, we use the inverse labour supply $w^{i}=w^{i}\left(L^{i}, L^{j}\right)$, with $w_{i}^{i}>0$ and $w_{j}^{i}>0$.

With SE investment we assume that, unlike with PA investment, $K$ does not enter firm $i$ 's production function directly, which allows us to distinguish clearly the effects of each type of investment; thus, $q^{i}=q^{i}\left(L^{i}\right)$. Importantly, investment now shifts the labour supply curve. Hence, we have $L^{i}=L^{i}\left(w^{i}, w^{j}, K\right)$, with $L_{K}^{i}>0$, and $L^{j}=L^{j}\left(w^{i}, w^{j}\right)$ when firms choose wages. When firms set employment levels, $w^{i}=w^{i}\left(L^{i}, L^{j}, K\right)$ with $w_{K}^{i}<0$ and $w^{j}=w^{j}\left(L^{i}, L^{j}\right)$.

\section{The investment taxonomy under oligopsony}

We now derive optimal investment strategies under oligopsony. In compact notation, we have $\pi^{i}=\pi^{i}\left(A^{i}, A^{j}, K\right)$ and $\pi^{j}=\pi^{j}\left(A^{i}, A^{j}\right)$. Using backward induction, we first turn to the second period. Firm $i$ chooses its profit-maximising action given its rival's action, implying

$\pi_{i}^{i}=p q_{A^{i}}^{i}-\left(w^{i} L_{A^{i}}^{i}+L^{i} w_{A^{i}}^{i}\right)=0$

For brevity, we define $q_{A^{i}}^{i} \equiv q_{L^{i}}^{i} L_{A^{i}}^{i}$. Under wage competition, $L_{A^{i}}^{i}=L_{w^{i}}^{i}$ and $w_{A^{i}}^{i}=1$, while $L_{A^{i}}^{i}=1$ and $w_{A^{i}}^{i}=w_{L^{i}}^{i}$ under employment competition.

Expression (4) determines firm $i$ 's best response function, $A^{i}=\psi^{i}\left(A^{j}\right)$, for a given level of investment. Similarly, firm $j$ 's best response function, $A^{j}=\psi^{j}\left(A^{i}\right)$, is obtained from $\pi_{j}^{j}=0$. It will prove useful to sign the slope of $\psi^{j}\left(A^{i}\right)$. Total differentiation of $\pi_{j}^{j}=0$ gives $\psi^{j}{ }^{\prime}\left(A^{i}\right) \equiv d A^{j} / d A^{i}=-\pi_{j i}^{j} / \pi_{j j}^{j}$. Note that $\pi_{j i}^{j}>0$ under wage competition, 
assuming that $L_{j i}^{j}$, if negative, is sufficiently small in absolute value (which is in line with the normal standard assumption); under employment competition $\pi_{j i}^{j}<0$, assuming that $w_{j i}^{j}$, if negative, is sufficiently small in absolute value ${ }^{3}$. Thus, since $\pi_{j j}^{j}<0$ from the second-order conditions, $\psi^{j}{ }^{\prime}\left(A^{i}\right)>0$ under wage competition and $\psi^{j^{j}}\left(A^{i}\right)<0$ under employment competition. Using terminology introduced by Bulow, Geanokopolos and Klemperer (1985) in the oligopoly literature, wages are strategic complements whereas employment levels are strategic substitutes.

Turning to period one, firm $i$ maximises profits with respect to $K$, taking into account the effect of investment on profits through its rival's second-period action $\left(\pi_{j}^{i}\left(d A^{j} / d K\right)\right)$ :

$$
\frac{d \pi^{i}}{d K}=\pi_{K}^{i}+\pi_{j}^{i} \frac{d A^{j}}{d K}=0
$$

The second term in expression (5) is the strategic term. In the absence of strategic behaviour, firm $i$ would choose $K$ such that $\pi_{K}^{i}=0$. If, however, the strategic term is positive or negative, the firm will -relative to the non-strategic benchmark- overinvest $\left(\pi_{K}^{i}<0\right)$ or underinvest $\left(\pi_{K}^{i}>0\right)$, respectively. Characterising strategic investment behaviour requires signing the strategic term. Assuming that the sign of $\pi_{i}^{j}$ is the same as the sign of $\pi_{j}^{i}$ (see also Tirole (1988), p.326), and since $\frac{d A^{j}}{d K}=\psi^{j^{\prime}}\left(A^{i}\right) \frac{d A^{i}}{d K}$, we have $\operatorname{sign}\left(\pi_{j}^{i} \frac{d A^{j}}{d K}\right)=\operatorname{sign}\left(\pi_{i}^{j} \frac{d A^{i}}{d K}\right) \times \operatorname{sign}\left(\psi^{j \cdot}\left(A^{i}\right)\right)$

From our earlier discussion, we know the sign of $\psi^{j}{ }^{\prime}\left(A^{i}\right)$. The other term on the right hand side in expression (6) comprises of the effect of a firm's action on rival profitability (the "friendliness" term ${ }^{4}$ ), $\pi_{i}^{j}$, and the effect of investment on the firm's own action, $d A^{i} / d K$. Since $\pi_{i}^{j}=\left(p q_{L^{j}}^{j}-w^{j}\right) L_{i}^{j}$ under wage competition and $\pi_{i}^{j}=-L^{j} w_{i}^{j}$ under

\footnotetext{
${ }^{3}$ More specifically, $\pi_{j i}^{j}=\left(p^{j} q_{L^{j} L^{j}}^{j} L_{j}^{j}-1\right) L_{i}^{j}+\left(p^{j} q_{L^{j}}^{j}-w^{j}\right) L_{j i}^{j}$ when $A^{h}=w^{h}$ and $\pi_{j i}^{j}=-\left(w_{L^{i}}^{j}+L^{j} w_{j i}^{j}\right)$ when $A^{h}=L^{h}$. With linear labour supplies, both $L_{j i}^{j}$ and $w_{j i}^{j}$ are zero.

${ }^{4}$ This term was first introduced by Brander (1995, p.1415).
} 
employment competition, actions in oligopsony are always "unfriendly" $\left(\pi_{i}^{j}<0\right)$. An expression for $d A^{i} / d K$ is obtained by total differentiation of second-period first-order conditions with respect to $K$ :

$\frac{d A^{i}}{d K}=-\frac{\pi_{i K}^{i} \pi_{j j}^{j}}{\pi_{i i}^{i} \pi_{j j}^{j}-\pi_{j i}^{j} \pi_{i j}^{i}}$

with stability requirement $\pi_{i i}^{i} \pi_{j j}^{j}-\pi_{j i}^{j} \pi_{i j}^{i}>0$ and $\pi_{j j}^{j}<0$ from the second-order conditions.

The sign of $d A^{i} / d K$ is the same as the sign of $\pi_{i K}^{i}$ and hinges on the type of investment considered. We now discuss the investment taxonomy for PA and SE investment, respectively.

\subsection{Productivity-augmenting investment}

Under PA investment, $\pi_{i K}^{i}=p^{i} q_{A^{i} K}^{i}>0$ since $q_{A^{i} K}^{i}>0$. Hence, $d A^{i} / d K>0$ both under wage and employment competition. This, combined with the fact that actions are "unfriendly", implies that PA investment always makes the investing firm "tough" $\left(\pi_{i}^{j} \frac{d A^{i}}{d K}<0\right)$. When firms set wages -bearing in mind that $\psi^{j}{ }^{\prime}\left(A^{i}\right)>0-$, the strategic term is negative $\left(\pi_{j}^{i} \frac{d A^{j}}{d K}<0\right)$. Therefore, $\pi_{K}^{i}>0$ (from expression (5)), which indicates that strategic behaviour involves underinvestment. In the Fudenberg-Tirole (1984) terminology, the firm plays "puppy dog" under wage competition, that is, it chooses to be small and inoffensive. Intuitively, because the investing firm knows a high rival wage reduces its own profits, it wants to suppress it. Given the strategic complementarity between wages, this necessitates a commitment by firm $i$ to a low wage (relative to the non-strategic benchmark). Underinvestment ensures a low future wage since it keeps a firm's labour productivity low.

Figure 1 shows second-period reaction functions when firms set wages. $\mathrm{N}$ denotes the equilibrium when firms invest non-strategically. Firms $i$ 's profits increase as $w^{j}$ 
decreases. Strategic investment shifts firm i's reaction function to the left, resulting in the equilibrium denoted by S. At $\left(w^{i S}, w^{j S}\right)$, wages are lower than in the non-strategic benchmark.

Note that, under employment competition, the strategic term is positive $\left(\pi_{j}^{i} \frac{d A^{j}}{d K}>0\right)$ because PA investment makes the investing firm "tough" $\left(\pi_{i}^{j} \frac{d A^{i}}{d K}<0\right)$ and the rival's best response function is negatively sloped $\left(\psi^{j}{ }^{\prime}\left(A^{i}\right)<0\right)$. Hence, $\pi_{K}^{i}<0$ and firm $i$ plays "top dog", or, overinvests, thereby reducing rival employment, to look big and aggressive.

\subsection{Supply-enhancing investment}

Our discussion now turns to strategic behaviour under SE investment. Under wage competition, $\pi_{i K}^{i}=\left(p^{i} q_{L^{i} L^{i}}^{i} L_{i}^{i}-1\right) L_{K}^{i}+\left(p^{i} q_{L^{i}}^{i}-w^{i}\right) L_{i K}^{i}<0 \quad$ (assuming $\quad L_{i K}^{i}$ is not too positive) and hence $d A^{i} / d K<0$, implying that SE investment makes the investing firm "soft". Strategic investment thus involves adopting a "fat cat" attitude: overinvest to look big and inoffensive. SE investment shifts down the labour supply curve facing the firm, lowering the reservation wage as non-wage benefits to workers increase. Apart from lowering the firm's own wage, this also reduces the rival's wage. Finally, under employment competition, $\pi_{i K}^{i}=-\left(w_{K}^{i}+L^{i} w_{i K}^{i}\right)>0$ (assuming $w_{i K}^{i}$ is not too positive) and hence $d A^{i} / d K>0$. So, like with PA investment, a strategically investing firm adopts a "top dog" stance under employment competition.

Table 1 summarises our discussion of strategic investment behaviour under oligopsony ${ }^{5}$.

\section{Concluding remarks}

\footnotetext{
5 Strategic investment to deter firm entry in the labour market seems less plausible. It is, however, straightforward to expand the taxonomy to incorporate this case.
} 
It is worthwhile pointing out that existing labour market policies may have implications for strategic investment behaviour. We focus on the effects of a minimum wage, $\underline{w}$, using figure 1 in our explanation. Assume $\underline{w}>\min \left(w^{i S}, w^{j S}\right.$ ) (in figure $\left.1, \underline{w}>w^{i S}\right)$. At $\underline{w}$, firms' reaction functions exhibit a kink. Firm $i$ 's incentive for strategic behaviour is now mitigated as its own wage (and indeed the rival's wage) cannot be pushed below $\underline{w}$. In figure 1, firm $i$ shifts its reaction function only to point M. In the case of PA investment, firm $i$-although still underinvesting- now invests more than in the case without the minimum wage. With SE investment, firm $i$ overinvests less, which implies that workers -although paid more- receive fewer non-wage benefits on the job. 


\section{References}

Brander, J. (1995), "Strategic trade policy", in Grossman, G. and K. Rogoff (eds.), Handbook of International Economics, Volume III, Amsterdam: North-Holland, 1395-1455.

Bulow, J., J. Geanokopolos and P. Klemperer (1985), "Multimarket oligopoly: strategic substitutes and complements", Journal of Political Economy, 93, 488-511.

Fudenberg, D. and J. Tirole (1984), "The fat cat effect, the puppy dog ploy and the mean and hungry look", American Economic Review, Papers and Proceedings, 74, 361368.

Jun, B. and X. Vives (2004), "Strategic incentives in dynamic duopoly", Journal of Economic Theory, 116, 249-281.

Lapham, B. and R. Ware (1994), "Markov puppy dogs and related animals", International Journal of Industrial Organization, 12, 569-593.

Manning, A. (2003), Monopsony in Motion. Imperfect Competition in Labor Markets, Princeton: Princeton University Press.

Neary, J.P. and D. Leahy (2000), "Strategic trade and industrial policy towards dynamic oligopolies", Economic Journal, 110, 484-508.

Tirole, J. (1988), The Theory of Industrial Organization, Cambridge: MIT Press. 
Table 1: The Fudenberg-Tirole taxonomy for oligopsony

\begin{tabular}{|c|c|c|}
\hline & Wage & Employment \\
\hline $\begin{array}{c}\text { Pnderinvest } \\
\text { Investment }\end{array}$ & {$\left[\pi_{i}^{j}\left(d A^{i} / d K\right)<0\right.$ and $\left.\psi^{j \prime}\left(A^{i}\right)>0\right]$} & Overinvest \\
\hline "PUPPY DOG" & {$\left[\pi_{i}^{j}\left(d A^{i} / d K\right)<0\right.$ and $\left.\psi^{j{ }^{\prime}}\left(A^{i}\right)<0\right]$} \\
$\begin{array}{c}\text { SE } \\
\text { Investment }\end{array}$ & $\begin{array}{c}\text { Overinvest } \\
{\left[\pi_{i}^{j}\left(d A^{i} / d K\right)>0 \text { and } \psi^{j \prime}\left(A^{i}\right)>0\right]}\end{array}$ & $\begin{array}{c}\text { Overinvest } \\
{\left[\pi_{i}^{j}\left(d A^{i} / d K\right)<0 \text { and } \psi^{j \prime}\left(A^{i}\right)<0\right]} \\
\text { "FAT CAT" }\end{array}$ \\
\hline
\end{tabular}


Figure 1: Strategic investment in a wage-setting oligopsony

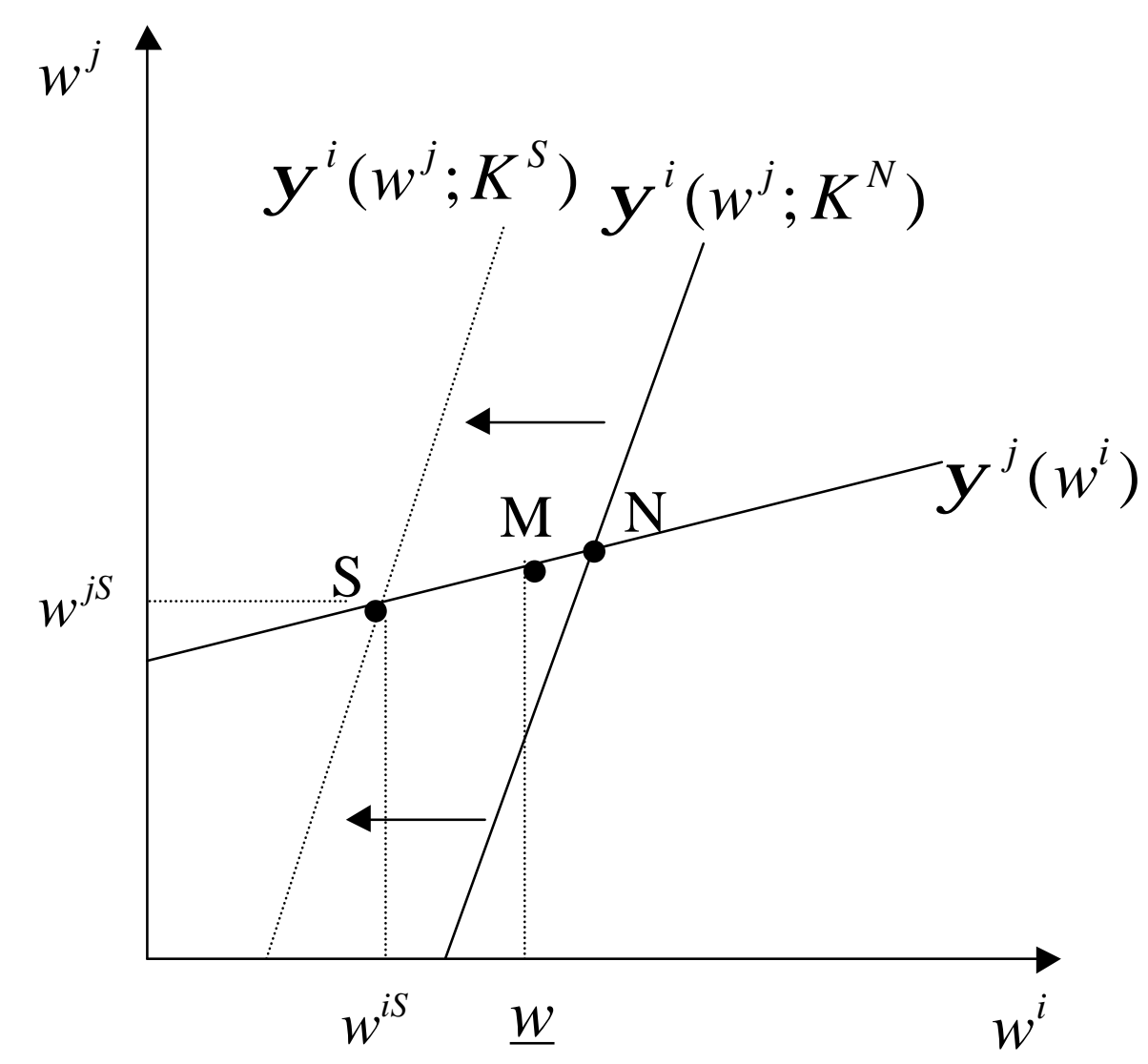

Note: $K^{N}$ and $K^{S}$ denote the non-strategically and strategically chosen level of $K$, respectively. 